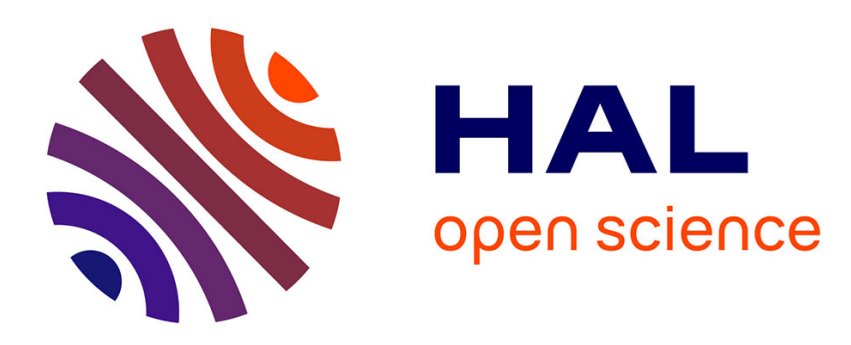

\title{
CO-laser photoacoustic spectroscopy on dimerization of fatty acid, molecules
}

\author{
R. Kästle, M. Sigrist
}

\section{To cite this version:}

R. Kästle, M. Sigrist. CO-laser photoacoustic spectroscopy on dimerization of fatty acid, molecules. Journal de Physique IV Proceedings, 1994, 04 (C7), pp.C7-491-C7-494. 10.1051/jp4:19947115 . jpa00253168

\section{HAL Id: jpa-00253168 https://hal.science/jpa-00253168}

Submitted on 1 Jan 1994

HAL is a multi-disciplinary open access archive for the deposit and dissemination of scientific research documents, whether they are published or not. The documents may come from teaching and research institutions in France or abroad, or from public or private research centers.
L'archive ouverte pluridisciplinaire HAL, est destinée au dépôt et à la diffusion de documents scientifiques de niveau recherche, publiés ou non, émanant des établissements d'enseignement et de recherche français ou étrangers, des laboratoires publics ou privés. 
JOURNAL DE PHYSIQUE IV

Colloque C7, supplément au Journal de Physique III, Volume 4, juillet 1994

\title{
CO-laser photoacoustic spectroscopy on dimerization of fatty acid molecules
}

R. Kästle and M.W. Sigrist

ETH Zurich, Institute of Quantum Electronics, 8093 Zurich, Switzerland

\begin{abstract}
Absorption spectra of fatty-acid molecules with carbon number below five were recorded as a function of temperature and partial pressure in the $1560-1950 \mathrm{~cm}^{-1}$ wavelength range using photoacoustic spectroscopy with a $\mathrm{CO}$ laser as radiation source. A special Helmholtz PA cell providing good temperature uniformity and stability was developed and used to study flowing gaseous mixtures at varying temperatures. Dimerization enthalpies $\Delta \mathrm{H}$ for acetic $(\Delta \mathrm{H}=$ $60.8 \pm 3.5 \mathrm{~kJ} / \mathrm{mole})$, propionic $(\Delta \mathrm{H}=62.4 \pm 4.0 \mathrm{~kJ} / \mathrm{mole})$, acrylic $(\Delta \mathrm{H}=61.0 \pm 3.5 \mathrm{~kJ} / \mathrm{mole})$ and butyric $(\Delta \mathrm{H}=58.7 \pm 1.0 \mathrm{~kJ} / \mathrm{mole})$ acid agree well with values obtained by other methods.
\end{abstract}

\section{INTRODUCTION}

Since hydrogen bonds play a key role in chemistry and biology there is a great interest in hydrogen-bonded molecules. Simple examples of such systems are fatty acid dimers. Owing to their geometry and strong $\mathrm{H}-$ bonds, two monomers build a planar ring (see Fig. 1) with a $\mathrm{C}_{2 \mathrm{~h}}$ symmetry which is stable even at room temperature. The binding enthalpies of these dimers are on the order of a few $\mathrm{kT}$ which means that their concentration in a gas sample is negligible when the temperature is increased to $50^{\circ} \mathrm{C}$ above that of the ambient. For this reason, fatty acid molecules are well suited to study chemical equilibrium reactions with relatively simple spectroscopic techniques.<smiles>[R]C(=O)O</smiles>

Figure 1: $\quad$ Fatty-acid monomer ( $\mathrm{R}$ represents a chain of carbon atoms)<smiles>[R]C(=O)O[Hg]OC([R])=O</smiles>

Fatty-acid dimer

For approximately 60 years numerous studies on the dimerization enthalpies of various fatty acid molecules have been made. In earlier studies, authors selected the so called P-V-T method and measured the binding enthalpies $\Delta \mathrm{H}$ for the lowest two fatty acids (e.g., formic and acetic acid) in undiluted gas samples $[1,2,3]$. The disadvantage of this method is that errors due to wall adsorption have to be taken into account. In the last thirty years spectroscopic techniques, e.g., Infrared [4,5], FTIR [6] and Raman [7] spectroscopies were used to obtain $\Delta \mathrm{H}$, as fatty acids absorb strongly in the infrared region and exhibit well separated bands of monomers and dimers. However, these previous spectroscopic measurements were 
performed on stationary gas mixtures and are thus prone to adsorption effects resulting from a change of equilibrium between monomers $(\mathrm{m})$ and dimers (d) (partial pressure changes during a typical measuring time of one or two hours). In this paper results of first spectroscopic measurements on flowing gas mixtures, avoiding thus problems associated with wall adsorption, are being discussed.

\section{THEORY}

The theoretical treatment used in this work to determine dimerization enthalpies of fatty acids $(\mathrm{m}=$ monomer, $d=$ dimer) is essentially that of Pross and van Zeggeren [5]. For a reaction

$$
m+m \leftrightarrow d
$$

one can define the equilibrium constant $\mathrm{K}_{\mathrm{p}}$

$$
K_{p}=\frac{p_{d}}{p_{m}^{2}}
$$

(where $p_{d}, p_{m}$ are the partial pressures of dimers and monomers). When replacing the partial pressures by corresponding concentrations $c_{d}$ and $c_{m}$, one has:

$$
K_{p}=\frac{c_{d}}{c_{m}^{2} R T}=\frac{n_{d}}{n_{m}^{2}} * V_{c e l l} * \frac{l}{X}
$$

(where $n_{d}, n_{m}$ represent the number of dimers and monomers, $V$ is the volume of the PA cell and $X$ is the mixing ratio). The second expression of eq.(3) considers the case when measurements are made in a continuous stream of fatty acid molecules diluted at different mixing ratios $\mathrm{X}$ in synthetic air $\left(80 \% \mathrm{~N}_{2}\right.$ / $20 \% \mathrm{O}_{2}$ ). From eq. (3) one can derive the Van't Hoff law:

$$
\left[\frac{d \ln K(T, p)}{d(1 / T)}\right]_{p}=\frac{d \ln \left[\left(c_{d} / c_{m}^{2}\right) * \frac{I}{T}\right]}{d(1 / T)}=\frac{\Delta H}{R}
$$

By measuring concentrations of monomers and dimers using photoacoustic spectroscopy (PAS), the dimerization enthalpies can be derived directly from Van't Hoff's law by plotting $\ln \left(c_{d} /\left(c_{m}{ }^{2} * T\right)\right.$ versus $1 / T$.

\section{EXPERIMENTAL}

\subsection{The apparatus}

The dimerization enthalpy $\Delta \mathrm{H}$ of fatty acid molecules was determined using photoacoustic spectroscopy (PAS) with a modified set-up used previously for trace gas analysis [8]. The spectral range of our instrument was extended by reducing the temperature of the CO-laser (Edinburgh Instruments PL03) to $230 \mathrm{~K}$ using ethanol as cooling liquid. The laser now emits on 90 transitions with a maximum output power of 3.1 Watt within the 1650 to $1950 \mathrm{~cm}^{-1}$ wavenumber range. The laser radiation is modulated by a mechanical chopper and split on a beam divider. A minor fraction is directed toward a pyroelectric detector while the remaining part traverses the photoacoustic cell before being detected by a power meter to allow simultaneous measurements of photoacoustic and transmitted signals. The microphone and detector signals are processed with Lock-in Amplifiers (Ithaco Dynatrac 393) and are recorded on a personal computer via a control work station (Keithley S 570). The entire system is automated using a IBM AT computer. 


\subsection{PA cell and gas filling system}

The PA chamber consists of an inner copper cell surrounded by a stainless steel jacket, both are placed in a thermostat bath (temperature can be varied from 275 to $350 \mathrm{~K}$ with an accuracy of $\pm 0.5 \mathrm{~K}$ ). The condenser microphone (Brüel \& Kjaer Type 4179 , sensitivity $107 \mathrm{mV} / \mathrm{Pa}$ ) is connected to the inner cell via a thin pipe in order to avoid its heating. At a frequency of about $400 \mathrm{~Hz}$ this cell acts as a Helmholtz resonator (see Fig. 2).

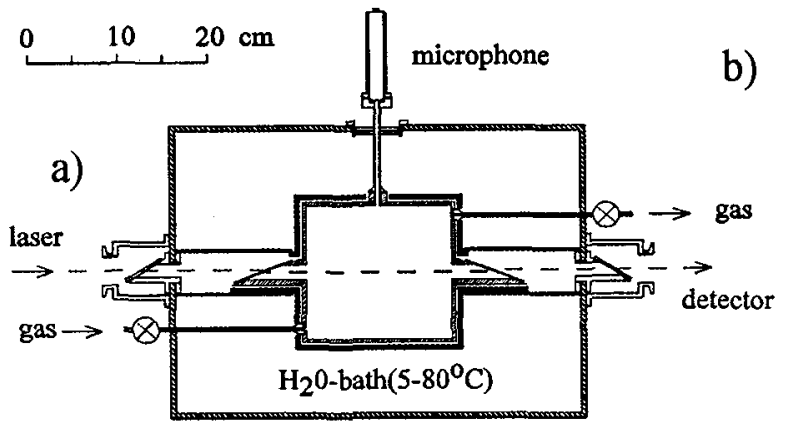

copper cell

stainless steel

isolation box

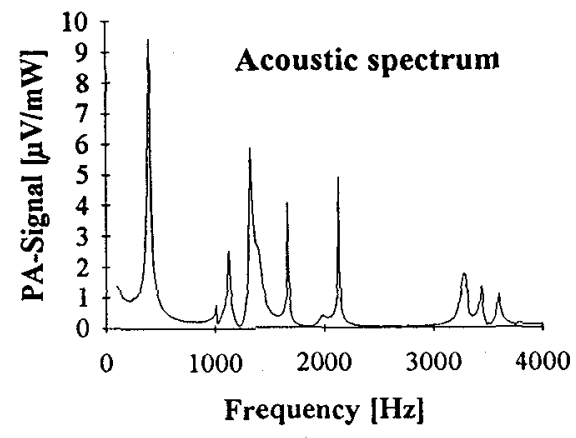

Figure 2: Photoacoustic cell (a) and its acoustic spectrum (b)

The measurements were performed on continuously flowing streams of gaseous fatty acid molecules buffered in synthetic air $\left(80 \% \mathrm{~N}_{2} / 20 \% \mathrm{O}_{2}\right)$ at atmospheric pressure. The mixture was prepared by diluting fatty acid vapor from a washing bottle (at a flow rate of ca. $1-10 \mathrm{ml} / \mathrm{min}$ ) with synthetic air (flow rate of $1 \mathrm{l} / \mathrm{min}$ ) in a gas mixing unit (MKS Instruments). Such gas system prevents effects of adsorption since the walls of our PA cell get saturated with fatty acid molecules and do not reduce the partial pressure even during extended periods of measurement.

\section{RESULTS}

From the PA spectra recorded at different temperatures (Fig.3) and based on Van't Hoffs law, enthalpies of dimerization $\Delta \mathrm{H}$ of fatty acid molecules with carbon number below five were derived.

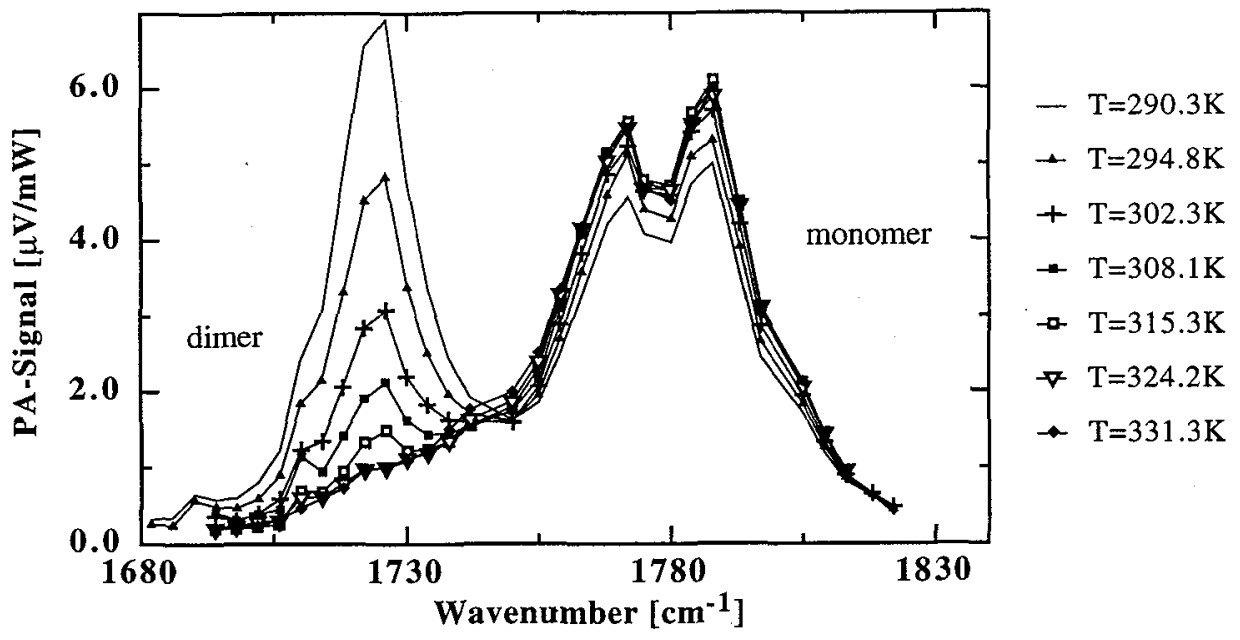

Figure 3: Photoacoustic spectra of propionic acid at different temperatures 
Figure 3 above shows normalized PA signals obtained for propionic acid. A decrease of the dimer band absorption with increasing temperature is clearly manifested. Obtained $\Delta H$ data are in agreement with those reported by various authors using other methods (see Table 1) including most recent measurements of Winkler et al. [9].

Table 1: Dimerization enthalpies $\Delta H$ of various fatty acids

\begin{tabular}{|c|c|c|c|}
\hline Fatty acid & $\Delta \mathbf{H}[\mathrm{kJ} / \mathrm{mole}]$ & authors & method \\
\hline \multirow{2}{*}{ acetic acid } & $61.5 \pm 2.5$ & this study & PAS \\
\cline { 2 - 4 } & $62.6 \pm 0.6$ & Winkler et al.[9] & PAS \\
\cline { 2 - 4 } C-COOH & $70.3 \pm 3.2$ & Pross / van Zegerren[5] & IR-Spectroscopy \\
\cline { 2 - 4 } & $60.3 \pm 2.5$ & Jaffe / Rose[6] & Raman \\
\hline propionic acid & $62.3 \pm 2.5$ & this study & PAS \\
\cline { 2 - 4 } C-C-COOH & $61.3 \pm 0.5$ & Winkler et al. & PAS \\
\hline \multirow{2}{*}{$\begin{array}{c}\text { acrylic acid } \\
\text { C=C-COOH }\end{array}$} & $61.0 \pm 3.5$ & this study & PAS \\
\cline { 2 - 4 } & 77.4 & Büttner / Maurer[3] & P-V-T \\
\hline butyric acid & $58.4 \pm 1.0$ & this study & PAS \\
\cline { 2 - 4 } C-C-C-COOH & $64.9 \pm 3.0$ & Clague / Bernstein[4] & IR-Spectroscopy \\
\hline
\end{tabular}

\section{OUTLOOK AND CONCLUSION}

The PA spectroscopy with a CO-laser has been applied for the first time to flowing mixtures of fatty acid vapors buffered in synthetic air. Besides obtainig dimerization enthalpies $\Delta H$, the objective of our present studies is to determine absolute line intensities of monomer and dimer absorption. Finally, anticipated PA studies on binary mixtures of fatty acids and water vapor are expected to provide new insights into processes of association in such samples.

This project is supported by the EC-SCIENCE Program.

\section{References}

[1] Ritter H., Simons J., J. Amer. Chem. Soc. 67 (1945) 757-762

[2] Johnson J., Nash L., J. Amer. Chem. Soc. 72 (1950) 547-556

[3] Büttner R., Maurer G., Ber. d. Bunsenges. Phys. Chem. 87 (1983) 877-882

[4] Clague A., Bernstein H., Spectrochimica Acta 25A (1969) 593-596

[5] Pross A., van Zegerren F., Spectrochimica Acta 16 (1960) 563-569

[6] Jaffe D., Rose N., Spectrochimica Acta 47A (1991) 1695-1705

[7] Gauffrès R., Maillols J., Tabacik V., J. Raman Spectr. 11 (1981) 442-448

[8] Bernegger S., Sigrist M.W., Infrared Phys. 30 (1990) 375-429

[9] Winkler A. et.al., Dig. 8th Int. Top. Meeting on Photoacoustic and Photothermal Phenomena, Point-à -Pitre (Guadeloupe, F), Jan 22-25,1994, paper GO-04 